\title{
Chapter 3 \\ Can Natura 2000 Sites Benefit from River Basin Management Planning Under a Changing Climate? Lessons from Germany
}

\author{
Lars Stratmann and Juliane Albrecht
}

\begin{abstract}
Goals for nature conservation and development are set for several rivers and lakes which are situated within protected areas. Concurrently these areas have to meet the requirements of the Water Framework Directive. Between the goals of both scopes there are often synergies but partially conflicts. In addition, climate change, which touches both water management and nature conservation at the same time, has to be taken into account during the river basin management planning, too. Against this background it is discussed in consideration of climate change, how the goals of nature conservation and of the Water Framework Directive can be achieved in such a way that conflicts are avoided to a large extent and synergies used. The following discussion and its results are based on an evaluation of the river basin management plans and programmes of measures in the ten river catchment areas of Germany. Altogether, it can be noticed that potential synergies are already put to good use. However, there are even more unused possibilities for the improvement of the interplay of nature conservation and Water Framework Directive as well as for the consideration of climate change effects.
\end{abstract}

Keywords Water framework directive - Nature conservation - River basin management plan - Programme of measures - Climate change

\subsection{Introduction}

At present, the Water Framework Directive (WFD) is implemented in the Member States of Europe. In this context, programmes of measures and river basin management plans had to be drawn up by 2009 for the attainment of a good water

L. Stratmann · J. Albrecht $(\square)$

Leibniz Institute of Ecological Urban and Regional Development, Weberplatz 1,

01217 Dresden, Germany

e-mail: j.albrecht@ioer.de

(C) The Author(s) 2015

S. Ignar and M. Grygoruk (eds.), Wetlands and Water Framework Directive,

GeoPlanet: Earth and Planetary Sciences, DOI 10.1007/978-3-319-13764-3_3 
status. In doing so, spatial overlapping of nature conservation goals and of goals of the WFD is recognised within many floodplains and wetlands in Europe. The question arises: To what extent a content-related coordination of overlapping goals of nature conservation and WFD has been carried out within the first planning phase until the end of 2009. Such coordination seems reasonable to avoid conflicts between measures of the WFD and aims of nature conservation areas as well as to use synergy potentials specifically. The integration of climate change in the river basin management planning according to WFD and in the management planning for Natura 2000 areas is increasingly meaningful. This applies particularly to the current phase of up-dating of plans and programmes in accordance with WFD until the end of 2015. For current and future planning activities it is important to assess how the goals of WFD, of nature conservation and of climate change adaptation and mitigation were integrated into the plans and programmes till now.

Therefore, the German Federal Agency for Nature Conservation has commissioned a research project regarding the assessment of the river basin management plans (RBMP) and programmes of measures (PoM) in the German river basin districts in view of the consideration of aspects of nature conservation. The project is entitled "Implementation of the WFD from the Perspective of Nature Conservation-Analysis of the River Basin Management Planning" (FKZ 350983 0100) and was conducted by the Leibniz Institute of Ecological Urban and Regional Development (IOER) in cooperation with the Chair of Landscape Planning at the Technische Universität Dresden (Albrecht et al. 2012). The project focused on identifying the overlap between river basin management planning and nature conservation and included the assessment of the plans with regard to the consideration of nature conservation aspects. Recommendations for the optimal integration of nature conservation into the planning documents in the future were given. The project revealed important knowledge regarding the content and procedure of planning as well as the consideration of the aims of nature conservation, especially in Natura 2000 sites. The findings will be reported in the following article and are intended to be used in the second planning period.

The following essay is subdivided into three sections. At first the river basin management planning is introduced as a planning instrument for the attainment of the aims of the WFD. In this chapter, the contents of the RBMP and the PoM and the different levels of planning in accordance with WFD are explained (Sect. 3.2). The second section explains the implementation of river basin management planning within protected areas. Therefore, the consideration of protected areas throughout the implementation of the WFD is described in detail, and cooperation and participation means for the integration of conservation aspects into river basin management planning are introduced (Sect. 3.3). Then it is examined how the goals of the WFD can be accomplished even under the influence of a changing climate. In fulfilling this task, opportunities in the context of the scheduled planning instruments and steps are discussed and recommendations given (Sect. 3.4). Finally, conclusions are drawn and an outlook on future implementation is given (Sect. 3.5). 


\subsection{RBMP As a Key Instrument to Achieve the Objectives of the WFD}

The WFD provides two planning instruments for achieving the objectives of Art. 4: the programme of measures (Art. 11 WFD) and the river basin management plan (Art. 13 WFD). Together, these two planning instruments form the basis for a coherent, all-embracing management concept for river basins. Article 3 WFD establishes the river basin as the spatial unit for water management planning. Member States have to identify river basins within their territory and assign them to river basin districts (Art. 1 para. 3 WFD).

River basin management planning and especially the selection of appropriate measures are key instruments to achieve the objectives of Article 4 WFD and have to be coordinated with the objectives of nature conservation. In EC-DGEnv (2010), a dialogue on the programme of measures of WFD at an early stage was identified as a tool for the coordination of the objectives of the WFD on the one hand and the objectives of the HD and BD on the other hand. Since the end of 2009, programmes of measures (Art. 11 WFD) and river basin management plans (Art. 13 WFD) are available in most Member States of the EU.

\subsubsection{Content of the Programmes of Measures and River Basin Management Plans}

The programme of measures sets out the actions to be taken during the implementation period to achieve the objectives of Art. 4 WFD (Czychowski and Reinhardt 2010, Section 82 marginal no. 2). Each programme of measures contains basic and, where necessary, supplementary measures (Art. 11 para. 2 WFD). Basic measures have to be carried out regardless of the present status of water bodies (Rechenberg et al. 2000, p. 41). This is to avoid impairing the quality of ecologically intact water bodies. Supplementary measures are defined in Article 11 para. 4 sentence 1 of the WFD as measures that are planned and realized by Member States to achieve the objectives of Article 4. Such measures have to be taken if the basic measures are not sufficient to achieve the good water status (Seidel and Rechenberg 2004 , p. 213, 219). The river basin management plan concretises the objectives of Article 4 WFD for each water body and documents all steps of river basin management planning (cf. Art. 13 WFD). A summary of the PoM is included in the RBMP, too (cf. Annex VII No. 7 WFD).

Public consultation plays an important role during the whole implementation process of the WFD. Thus, Member States shall encourage the active involvement of all interested parties in particular in the preparation, review and updating of the RBMP (cf. Art. 14 para. 1 WFD). Regarding the production, review and updating of the PoM, public participation is not explicitly mentioned in Art. 14 WFD. However, programmes of measures are subject to Strategic Environmental Assessment (SEA) 
according to Article 2 a, Art. 3 para. 1, 2 a, b and para. 5, and Annex II SEADirective, which also requires public participation (Art. 6 SEA-Directive) (cf. Carter and Howe 2006, p. 288 et seq.). Therefore, the PoM is subject to public participation, too. Moreover, the PoM can be also subject to the Habitats Regulations Appraisal according to Article 6 para. 3 HD.

The RBMPs and the PoMs had to be finalized and published by 22 December 2009 at the latest (Art. 13 para. 6 and Art. 11 para. 7 WFD). They are to be reviewed and updated until 22 December 2015 and every 6 years thereafter (Art. 13 para. 7 and Art. 11 para. 8 WFD). Their cyclical updating is a refining process based on improved data and understanding and allowing for real changes of circumstances in the river basins (Foundation for Water Research 2012).

\subsubsection{Levels of River Basin Management Planning}

River basin districts cross not only the borders of a number of Federal States, but in some cases also national borders. Cross-border cooperation is thus obligatory for both states and countries when drawing up management plans and programmes of measures (Art. 3 and 13 WFD). This requires the coordination of the contents of PoMs and management plans across both state and national boundaries. Parts of a total of ten river basin districts lie in Germany (Danube, Elbe, Rhine, Eider, Schlei/ Trave, Weser, Oder, Meuse, Ems, Warnow/Peene).

The WFD stipulates that for river basin districts that lie wholly within the territory of a Member State, a management plan (national management plan) must be produced for the river basin district in question (Art. 13 para. 1 WFD). The drawing up of a single plan for international river basins is also desirable (international management plan). If no joint plans are produced, then the plans should at least cover that part of the river basin district that lies within the territory of the Member State (national management plan for part of the river basin district) (cf. Art. 13 para. 2 WFD). In Germany there are several cases where a number of planning documents have been produced that at different levels cover the same area of the river basin in question and also cases where a number of planning documents have been produced covering smaller, adjoining sub-areas of one river basin. For instance, for the Elbe a joint plan for the entire (international) river basin district has been published; in addition, a national management plan and its associated PoM including an environmental report have been produced; and, furthermore, supplementary plans for various sub-areas of the same river basin district have been produced and circulated at the level of the Federal States. For the national river basin of the Rhine there is no complete plan; the relevant plans have instead been produced for four national and five international planning areas. As a result, the first of the three planning phases of WFD implementation (up to the end of 2009) saw substantially more than ten PoMs and ten RBMPs being produced for the ten river basins in Germany (Posselt et al. 2012, p. 75 et seq.). There are, in addition, the environmental reports made on the PoMs within the framework of the SEA. 
Various national and international institutions (international river basin commissions, transboundary water commissions, national river basin associations) have been tasked with the coordination of plans (Posselt et al. 2012, p. 76). The aim of coordination is to draw up a management plan, including the PoM that contains binding specifications for all management measures and decisions within the river basin district (Ell 2003, p. 72; Spillecke 2000, p. 32). In order to achieve this, the specialist quality goals are aligned at the beginning of the planning process. This is ensured by a bottom-up approach in which responsible state authorities communicate results gathered, prepared and evaluated at the level of the district in question to the coordinating authorities (LAWA 2001, p. 10; Knopp 2005, pp. 25-26). This is at the same time associated with constant generalisation owing to the decreasing scale of perspective (Ell 2003, p. 71).

\subsection{Implementation of RBMP in Protected Areas}

The following discussion clarifies how protected areas are integrated into management and measures planning in Germany and what effects the programmes of measures can have on the protected areas. The section concludes with consideration of the environment assessment instruments: Strategic Environmental Assessment (SEA) and Habitat Regulations Appraisal (HRA).

\subsubsection{Consideration of Protected Areas in the Implementation of $R B M P$}

Evaluation of management plans and PoMs has shown that the requirements and goals of protected areas, particularly the Natura 2000 sites, are affected in many ways by management planning.

- Determining and mapping protected areas in the first cycle of management planning

With reference to the Habitats Directive, there are various opinions about which areas should be included in the list of protected areas in WFD management plans. Several authors include not only those areas protected under European law (Natura 2000 sites) but also elements of the biotope network (Art. 10 HD) and areas protected under national law that — based on Article 12 of the HD — serve to protect species listed in Annex IV of the Habitats Directive (Korn et al. 2005; Fuchs et al. 2010). In contrast, for instance, the German Working Group on Water Issues of the Federal States and the Federal Government (LAWA 2003) specifies that only all formally identified Natura 2000 sites should be considered. 
The minimal requirements of Annex IV of the WFD are applied in Germany; generally speaking: all plans include information on Natura 2000 sites, but just one plan includes further protected areas in its list of protected areas. All management plans list and describe in text the water-dependent Natura 2000 sites, but only the management plan of the Oder included all Natura 2000 sites (also, e.g., dry grassland). The Warnow-Peene plan considers only Natura 2000 sites that have been approved by the EU Commission. The Ems management plan additionally identifies water-dependent protected areas based on national legislation (Section 23 Federal Nature Conservation Act). In numerous plans, there was no description of the method used to determine the water-dependent protected areas; reference was rather made to background documents (Stratmann et al. 2012b, p. 94).

In most plans, information about protected areas was also provided in a printed map, in a few plans there was only a reference to an online map server. The presentations on the map servers were often linked to further attributes (e.g. standard spread sheets). Some but not all plans included a clear presentation of water body boundaries and protected areas together. As a result, a clear assignment of protected areas to water bodies was not always possible. In such cases the impact of planned measures on individual protected areas is thus not clearly identifiable, a factor that must be negatively assessed from a nature conservation perspective (Stratmann et al. 2012b, p. 96).

- Practices of Federal States with regards to the nomination of water-dependent Natura 2000 sites

There is great variety between some of the Federal States of Germany in terms of the choice of WFD relevant Natura 2000 sites intended to conserve habitats and species directly dependent on water. Most of the German non-city States base their choice of areas on water-dependent habitat types or species, but Saxony nominated all the Natura 2000 sites. The situation seems similar for Brandenburg. SaxonyAnhalt though used the depth of the water table as the criterion for determining the choice of the Natura 2000 sites with habitats and species directly dependent on water. When the range of species considered is examined, it becomes clear that North Rhine-Westphalia and Saarland list species from Annex IV of the HD, while the other states only consider species from Annex II. When nominating waterdependent bird protection areas, six non-city states considered not only the bird species from Annex I of the Birds Directive but also migratory birds as mentioned in Art. 4 para. 2 of the BD. In contrast Schleswig-Holstein and Thuringia restrict consideration to species from Annex I. There are also area-related criteria. Hesse and Thuringia explicitly mention that they set no minimum size for consideration, but in Bavaria and Baden-Wuerttemberg a minimum area of 5 ha of waterdependent habitat types per protected area was stipulated. These, however, only affected special areas of conservation (SACs) with no relevant water-dependent species (Hofmann and Schmidt 2012, p. 216).

In the documents investigated there is usually only brief mentioning of the procedure followed when nominating the relevant protected areas. It can be assumed that there are other more detailed differences between the procedures of 
the Federal States in addition to those that can be identified from these sources. For instance, the list of Annex I (HD) water-dependent habitat types found in Hesse includes woodrush and woodruff beech woods as well as bedstraw-oak-hornbeam woods as habitat types that are in some cases groundwater-dependent; however, these habitat types are not included in the list of water-dependent habitat types for Baden-Wuerttemberg or Bavaria (Hofmann and Schmidt 2012, p. 216).

Differences in the nomination of protected areas can lead to differences in terms of conservation objectives for protected areas. It is possible that the heterogeneity of nomination may cause delays in the first cycle of management planning due to supplementary assessments and appeals based on species conservation legislation (Fuchs et al. 2010, p. 38 et seq.). According to Fuchs et al. (2010), there are also significant differences in nomination procedures between the various European countries.

- Economic analysis of environmental costs for species and habitat types covered by the HD

The WFD intends that economic framework conditions are considered in management plans (the so-called economic analysis). The economic analysis is to be carried out as part of the inventory and should consider and present the four areas: economic significance of water uses, baseline scenario (forecast) of water uses up to 2015, recovery of costs of water services, and cost effectiveness of measures (cf. Annex III WFD).

From a nature conservation perspective this information can be of interest in a number of areas. Information about the economic significance of water uses and their future development (baseline scenario) may provide a basis for assessing current and future impacts on protected assets (Wendler et al. 2012, p. 50). On the one hand, the needs of nature conservation are to be considered when determining environmental and resource costs, and should also be included in the criteria used to assess the cost efficiency of measures. On the other hand, current forecasts about the future development of nature conservation issues (e.g., with regards to climate) form the basis of the baseline scenario, which in turn provides information about the future development of water supplies, are taking into account the influence of climate change. This section thus provides indications about whether objectives for certain planning units or water bodies may require modification in the future and also aids in the choice of measures that will be effective in the long-term (Stratmann et al. 2012b, p. 107).

However, there is currently a general lack of pragmatic, easy to handle, methodological approaches for including in the economic analysis environmental costs for species and habitat types covered by the HD. Furthermore, the terms 'water services' and 'water uses' are very narrowly interpreted in Germany, so that numerous impacts on species and habitats are not considered from an economic perspective (e.g. by hydroelectric power, flood defences). For these reasons, the environmental impacts and costs regarding Natura 2000 are not included in the economic analysis sufficiently. As long as these environmental costs are not internalised, protected areas will not be adequately assessed when decisions about uses are made (Stratmann et al. 2012a, p. 308 et seq.). 
Climate change is named as a basis for all or nearly all the baseline scenarios of water uses in the management plans. But so far climate change is said to have no influence on questions of water uses in the first phase of management planning (Stratmann et al. 2012b, p. 112). Therefore, climate change effects did not influence environmental costs for species and habitat types in Germany, but this might change in the next phases of management planning.

- Aspects and consequences of the planning of measures for Natura 2000 sites

As reference conditions for ecologically sound surface waters, the WFD uses waters largely undisturbed by humans, and thus formulates guiding principles that assume and promote self-driven processes and developments up to and including biocenoses specific to the individual water body type. It can therefore be assumed that the retention and development of natural and near-natural biocenoses in and on water bodies will benefit from far-reaching synergies between Natura 2000 and the WFD measures.

Nature conservation in Natura 2000 sites is concerned not only with the protection, management and development of natural biocenoses and habitats, but also in some cases with the protection of anthropogenically influenced biocenoses and the conservation and development of habitats and species of cultural landscapes. In addition, there are secondary biotopes that have developed in a fashion atypical to their locations following human intervention. These may be contrary to the process orientation of the WFD and its reference conditions for good ecological status, i.e., undisturbed by human activity. Conflicts in the implementation of Natura 2000 and the WFD could occur here and would need to be resolved (Hofmann and Schmidt 2012, p. 195 et seq.).

Key to achieving a good status for surface waters is the removal of hydromorphological impairments within the framework of the planning of measures in accordance with the WFD. Straightened river courses, cut-off side channels and floodplains that have been isolated by dykes are to be dealt with, for instance, by measures intended to improve aquatic habitats by adapting river courses, banks and beds, measures to initiate or allow the development of self-sustaining dynamic rivers, or measures to improve habitats within the development corridor (including the floodplain) of the water course. As well as the very positive effects of this in terms of natural water conditions, however, the use of such measures may lead to somewhat negative effects for species and habitats that are more culturally determined and for secondary biotopes that have developed atypically for their locations. Critical in this context are effects that lead to successive vegetation change on and around the waters towards vegetation types that are potentially natural today. Equally critical are changes to restore river regimes and the water logging or drying up of secondary biotopes. Furthermore, the reconnection of cut-off side channels, for instance, can end previous isolation from predators or illness (Hofmann and Schmidt 2012, p. 196 et seq.).

About 90 species from Annex II of the HD are relevant to surface waters or floodplains. Of these, it is predicted that about $40 \%$ will either be positively affected by the measures of the management plans and programmes of measures, or 
will experience no impact. About $60 \%$ of the species of community importance in Germany are considered to be in various ways sensitive to certain types of management planning measures. In individual cases these species could also be damaged by a lack of coordination between nature conservation and water management (Hofmann and Schmidt 2012, p. 214).

In order to substantiate this statement, certain types of measures were chosen for closer study. The results vary considerably. For instance, the planning units used for measures (and accompanying measures) to initiate or allow the development of selfsustaining dynamic rivers overlap with $90 \%$ of the areas protected under the HD in which potentially sensitive species of community importance are present. When reducing the backwater area is considered, it is found that this type of measure affects only $3 \%$ of the areas protected under the HD in which potentially sensitive species are present. The frequency of overlap obviously also reflects the basic frequency of the use of the measure in question (Hofmann and Schmidt 2012, p. 214).

This frequent overlapping of sensitive HD areas with planning units in which a potentially conflicting measure is to be undertaken does not, however, necessarily reflect the actual distribution density of conflicts. It is rather an initial indication of the large scale of the planning units and the abstract nature of the PoM. In the Federal States Bavaria, Brandenburg, Saxony und Schleswig-Holstein, where a detailed assignment of measures to water bodies was possible, the overlapping is much reduced. Indeed, then only 10-32\% of the sensitive HD areas overlap with water bodies where potentially conflicting types of measures were planned. It can be assumed that a spatially accurate assignment of the planned measures in other Federal States would also reveal a much reduced level of conflict (Hofmann and Schmidt 2012, p. 214 et seq.).

It is nonetheless regrettable that even in Federal States that work with spatially accurate assignments, there remains a not insignificant number of cases for which it is currently impossible to say whether the implementation of WFD measures would lead to conflicts with the conservation objectives of the Natura 2000 sites or not. In the management plans there are many references to coordination having taken place with nature conservation. However, the findings clearly show that in the further course of management plan implementation deepened coordination between water management and nature conservation is required to ensure that measures are compatible with the HD. Remaining issues can and must be rectified at the lower level, e.g. in the approval procedures (Hofmann and Schmidt 2012, p. 215).

- Consideration of nature conservation aspects in the SEA of the programme of measures

A strategic environmental assessment (SEA) is required for the programme of measures. This involves assessing the significant environmental effects expected from the contents of the PoM and comparing them to appropriate alternative measures. In order to achieve an effective assessment, the SEA must be integrated into the process of preparing the PoM. 
All of the PoMs investigated in Germany had undergone a SEA. Analysis of the environmental reports drawn up in the course of the SEAs showed that for the most part they contained the necessary information. However, the analysis also showed that the SEA was usually conducted on a smaller scale than that of the PoM. In most cases the assessment was carried out for planning units, coordination areas or the entire planning region. If the objects of assessment used for the SEA were more specific, then the environmental assessment could provide more detailed indications of significant effects on nature conservation issues. In addition, a targeted assessment of relevant cumulative effects on numerous successive or neighbouring water bodies, and also of the effects of single measures on entire river systems, would represent a qualified assessment of cumulative effects that could provide systemrelevant information about the development of special nature conservation issues (Stratmann et al. 2012c, p. 143).

There is no documentation of the assessment of alternatives in any of the environmental reports. In all the reports the assessment of alternatives was displaced either sideways (into the management plan that is not subject to the SEA) or in some cases downwards (to the next planning permission procedure). The examination of alternatives in the management plan was, however, not carried out in the formal framework of an environmental assessment, but rather in the planning stages of the river basin management plan and informal agreements with nature conservation. There was thus no documentation of assessments of conceptual, systematic or spatial alternatives. A significant element of the SEA was thus not applied (Stratmann et al. 2012c, p. 147 et seq.).

In the context of the sideways displacement of the examination of alternatives into the management plan, it was stated many times that alternatives had been discussed and evaluated during the management planning process, particularly at the local and regional level, and that alternatives had therefore already been assessed "outside" the planning of the PoMs. The argument is not fully convincing, because the planning period for both management plan and PoMs is the same. The documentation and review of comparisons with alternatives in terms of integrating aspects of nature conservation would thus have been possible (Stratmann et al. 2012c, p. 147).

Similarly to the examination of alternatives, the spatially defined, quantitative prognosis of effects was displaced to the next specific planning stage in all the environmental reports. This corresponds with the level of specification of the programme of measures, but it means that necessary agreements, for instance with nature conservation, had not yet been possible. The concern here is that, firstly, more time will be needed for agreement at the next planning stage, which could delay prompt implementation, and, secondly, desirable synergies or important conflicts will only be identified at this later planning stage where large-scale alternatives can no longer be chosen. This problem is further compounded by the fact that no water body specific environmental assessment is carried out, but only one at the scale of the planning units (Stratmann et al. 2012c, p. 147 et seq.).

- Habitats Regulations Appraisal and its role in integrating the objectives of RBMP and Natura 2000 
If stipulations of the PoM are spatially and content wise specific enough for a prognosis of their effects on the areas protected by the Habitats Directive to be possible, then effects relevant to nature conservation are also to be assessed using the framework of a Habitats Regulations Appraisal, in accordance with Art. 6 para. 3 of the HD and Sections 34 and 36 of the Federal Nature Conservation Act. For instance, the interaction of a number of WFD measures or types of measure along an extended river course, that mainly represents one Natura 2000 site, can be better assessed at a higher planning level than at the next small-scale concrete level where measures are implemented. The objects of assessment are the effects on protected habitat types (Annex I HD) and species (Annex II and IV HD) (Wendler et al. 2012, p. 62 et seq.).

The Habitats Regulation Appraisal was displaced to the next planning stage in almost all environmental reports. In only two cases was there a preliminary examination of the compatibility of the WFD measures with the objectives of the potentially affected Natura 2000 sites. The Habitats Regulation Appraisal was thus neither integrated in, nor linked to, the SEA for the PoM, but is for the most part to be carried out subsequently in connection with the environmental impact assessment of the planning approval procedure. This means that many of the necessary agreements and the integration of the objectives of the WFD areas with those of the Natura 2000 sites can only be undertaken at the time of project approval and not in advance. There was made no strategic distinction between Natura 2000 sites which protect natural processes and those which are conservation oriented on the level of the PoM or for specific water bodies. Subsequently the respective differences in compatibility of these categories of Natura 2000 objectives with measures of the PoM are not considered. It will be necessary to resolve conflicts of this sort at later planning stages, for instance through spatial separation and in certain circumstances the juxtaposition of naturally determined and culturally determined areas (Stratmann et al. 2012c, p. 148).

With management planning being undertaken for the first time, it was found that management plans with established objectives had not been finalised for numerous Natura 2000 sites. This represented a further hindrance to the coordination of Natura 2000 objectives with WFD activities. When the plans are next updated and continued - from 2013 onwards - it will be possible to use the objectives and measures of the existing Natura 2000 management plans for coordination. An attempt can be made to ensure that the WFD supports or integrates the measures contained therein (Stratmann et al. 2012c, p. 148).

\subsubsection{Cooperation and Participation to Include Nature Conservation in RBMP}

In addition to the issues of content and method already discussed, the involvement of nature conservation authorities and public participation can influence the integration of nature conservation matters into management planning. The following 
section thus considers several aspects related to the involvement of authorities and public participation.

- Short overview: Cooperation and integration of conservation and water management in RBMP in Germany

In order to ensure compatibility with the conservation objectives of the Natura 2000 sites, it is to be recommended that water management involve nature conservation at an early stage for measures in Natura 2000 sites or for measures that may influence such areas. Furthermore, can be recommended to prioritise the implementation of measures that have a positive effect in terms of both: the WFD and the HD and/or the BD. Lower Saxony provides an example of a state where procedures are based on consideration of Natura 2000 sites when prioritising measures (Hofmann and Schmidt 2012, p. 221).

The texts of the German management plans show that cooperation between nature conservation and water management for Natura 2000 sites is basically to be found in all the Federal States. Obviously the intensity of cooperation differed considerably from state to state and is reflected in the formal documents to a limited extent only. Firm cooperation between nature conservation and water management in terms of Natura 2000 and other specific nature conservation issues has not yet been established. But a close cooperation between nature conservation and water management will be of great significance in order to realise synergy effects in subsequent stages as planning becomes more concrete (Hofmann and Schmidt 2012, p. 221 et seq.).

Most of the management plans contain information about the way in which protection and conservation objectives of nature conservation areas were considered during management planning and the development of management aims. For example, the Weser management plan states that conflicting objectives were discussed between water and nature conservation authorities responsible. Either a solution was found that satisfied both sets of objectives, or a decision reached as to which objective was most important. In addition, in the course of planning measures for the Weser, an assessment was made of synergies between the objectives of the protected areas and management objectives, and it was determined which of these synergies it may be possible to exploit through the use of appropriate measures. Furthermore, the Natura 2000 objectives for water-dependent terrestrial ecosystems and aquatic habitats are given support. This is achieved by consideration of protection and conservation objectives, particularly for water-loving species and habitats within the frame of operational monitoring and when compiling the PoM and coordination of objectives with the nature conservation authorities (Stratmann et al. 2012b, p. 104).

Usually agreement with regards to the objectives of the Natura 2000 sites was reached early on with the authorities responsible for nature conservation. This is generally documented. Whether this mostly involved conservation (preservation of the status quo) or whether developmental aspects (e.g. protection of natural processes) with regards to Natura 2000 were also considered is not recorded in the management plans. It is therefore not possible to determine here whether the 
management plans primarily promote developmental aspects in Natura 2000 sites or whether conservation objectives in these areas are also supported, and if so to what extent (Stratmann et al. 2012b, p. 105).

However, not every management plan reveals the extent to which adequately concrete nature conservation objectives have contributed to the specification of management plan objectives. In order to understand the true facts of each case, it would be necessary to assess background documentation and/or conduct interviews (Wendler and Albrecht 2012, p. 37).

- Further needs for coordination and good practice examples

Potential conflicts can usually be solved if measures are coordinated - spatially and contentwise - synchronised and adapted to one another (cf. also Fuchs et al. 2010). In the course of drawing up the management plans, the necessary processes for agreement between water management and nature conservation have clearly begun, but they can in no way be regarded as complete. For a total of six types of measure in Germany as a whole there is, for example, overlapping between the planning units stipulated for the measure and between 67 and $95 \%$ of HD areas with species protected under the directive that are sensitive to the measure in question. Therefore, solutions have to be found on subsequent planning levels for the conflicts documented in the management plans (Hofmann and Schmidt 2012, p. 220 et seq.).

The intensive involvement of representatives of nature conservation on all levels of water management planning is the basic precondition for the emergence of winwin situations. A positive example of this is the specialist agreement made between water management and nature conservation administrations in Bavaria with regards to the hydromorphological programme of measures (Stratmann et al. 2012b, p. 117). In the course of drawing up this programme, Natura 2000 sites representing waterdependent habitat types where the habitat type was influenced by surface waters were considered. The water-relevant Natura 2000 conservation objectives specific to the areas in question were translated into corresponding hydromorphological measures, and agreement between the water management and nature conservation administrations reached. This procedure was documented in the environmental report for the PoM.

Frequently, however, it is not possible to determine the nature of cooperation between water management and nature conservation, at least not from the management plans and PoMs. This is partly because in many plans the composition of advisory boards is not detailed and individual actors remained unnamed. However, in all cases where the composition of advisory boards or forums or other participatory institutions was documented, then nature conservation representatives were included. In addition, representatives of agriculture, industry and commerce, mining, shipping, and cities and municipalities were involved (Stratmann et al. 2012b, p. 117 et seq.).

Formal public participation in the drafting of management plans varied greatly. In Bavaria, ca. 7,000 opinions were submitted and over 10,000 completed questionnaires were returned by post from France and Wallonia regarding the RBMP for the Rhine River. In the light of this considerable amount of participation, it should 
be analysed how best to achieve a significant increase in participation in the future in regions with low participation-also in order to know that the interests of nature conservation are more strongly represented among the local population (Stratmann et al. 2012b, p. 118).

In the opinions expressed formal, procedure-related and content-related aspects were addressed. The range of suggestions encompassed all topics touched upon by the WFD. A few management plans chose to document the opinions and technical suggestions through combining an aggregated summary of the most important aspects with a tabular list of all opinions received, and including also the administrative decisions as to how these opinions were integrated into planning. It was, however, not possible to detect any nature conservation focuses among the technical suggestions submitted (Stratmann et al. 2012b, p. 118).

\subsubsection{RBMP As a Tool for Achieving WFD Objectives in a Changing Climate}

Management planning offers many possible ways to adapt watercourses and groundwater, and their uses, to a changing climate. On the one hand, it is possible to influence the quantity and quality of water that will be available and be used in the future. On the other hand, the adaptation requirements of water-dependent habitats and species can be fulfilled.

Climate change issues are not explicitly mentioned in the WFD regulations that came into force in the year 2000. In the meantime, dealing with the effects of climate change is seen as one of the greatest challenges of the 21 st century (cf. Schuchardt et al. 2008). Scenarios of the global effects of climate change (cf. IPCC 2007) and their regionalisation (e.g. Endlicher and Gerstengarbe 2007) prove that for long-term strategies and measures there is an urgent need for action. The field of water management is particularly affected, because consequences for both water quality and water quantity are expected, accompanied by changes in ecological status, usability and the occurrence of extreme events such as flooding and low water levels (LAWA 2010). The report of the European Environment Agency on "Climate Change and Water Adaptation Issues" expresses the belief that in the light of climate change there is urgent need for European water management issues to be integrated with climate change adaptation measures (cf. EEA 2007). Taking into account climate change requires an integrated view of ecological and chemical water status and other fields such as flood risk management and land-use management (BMU 2007).

The European Commission has published two documents with far-reaching recommendations for CC adaptation: The Policy Paper "Climate Change and Water" (EC 2008) and the Guidance Document No. 24-"River Basin Management in a Changing Climate" (EC 2009). In general, it is stated in the documents that the step-wise and cyclical approach of the WFD makes it well suited to handle climate 
change (EC 2008, p. 4; similarly Reese 2011, who however postulates strict legal obligations for climate adaptation in water management). Climate change should at least be considered in the first planning cycle of river basin management planning, paving the way for more actions in the second and third cycles (EEA 2007, p. 27; BMU 2007, p. 4).

Requirements arising from climate change should thus be included in management planning. The recommendation for the current planning cycle is that the current state of knowledge and the effects of climate change should be described (cf. BMU 2007, p. 4; EC 2008, p. 4; EC 2009, p. 39). This can be included in discussion of the pressures on water bodies and the further development of assessment methods for ecological status (cf. Gammeltoft 2007).

Further WFD planning steps and instruments relevant to the focus on climate change are: monitoring and assessment of water status (Art. 8 WFD, Annex V), objective setting and making use of exemptions (Art. 4 WFD), the economic analysis (EC 2009, p. 39 et seq.).

Climate related objectives should be particularly considered when formulating and implementing environmental objectives and measures. On the one hand, it is necessary to reduce and avoid further climatic warming; and, on the other hand, adjustments to climate change must be attempted. Measures should thus be preferred that, in addition to their effectiveness in relation to WFD objectives, also reduce emissions of greenhouse gases (win-win measures) at the same cost. Similarly, preference should be given to measures with a high tolerance of climate change and that also remain effective and expedient despite greatly differing types of climatic change (no regret measures) (EC 2009, pp. 63-64).

Nature conservation and WFD can be well combined to achieve the greatest possible adaptability of water bodies and wetlands to climate change. Although there may be conflicts in individual cases (see above), in general, both strive to attain the goal of intact aquatic ecosystems, the qualities of which make a contribution to climate change adaptation. Such systems are characterised by varied hydromorphological structures, thus providing a retreat for aquatic fauna in stress situations, such as flooding or low water events. The continuity of watercourses allows resettlement by water-type specific species through migration, for instance after periods of drought. In the context of the apparent increasing necessity of low water management, further measures to improve water retention in the catchment should be planned. Such measures are of significance both to nature conservation and to the aims of the WFD, firstly in connection to the retention of diffuse substances in the catchment area and, secondly, in connection to the various environmental objectives of nature conservation, such as the extensive protection of a diversely structured landscape, soil protection and the safeguarding of balanced precipitation-runoff processes (Wendler et al. 2012, p. 55).

The issue of climate change and the necessary adjustments it implies have further connotations for nature conservation. It can be predicted that climate change will cause further changes in groundwater processes; these must then be incorporated in the planning of groundwater management and consideration of the effects on groundwater-dependent surface waters and terrestrial ecosystems (cf. LAWA 2009). 
Climate change can result in changes in habitats (e.g. for salmonids) and biocenoses in watercourses and lakes (e.g. through invasive species). This can in the long-term lead to a change in the reference conditions away from those laid out in the inventory. Clear conclusions can, however, not yet be drawn. Climate change scenarios forecast changes in the precipitation regime. This would then change runoff hydrographs with consequences for watercourses, and lead to longer periods of dryweather runoff conditions, longer periods of high runoff in winter and more frequent flooding events (Wendler et al. 2012, p. 55). Investigation of the consequences for aquatic biocenoses has hardly begun (Wulfhorst 2010, p. 89).

A further connection between management planning and nature conservation objectives is to be found with the issue of the protection and development of zones where cold and fresh air is produced. The presence and effectiveness of these zones depend partly on the distribution of water-dependent ecosystems, i.e. from surface water bodies and water-dependent terrestrial ecosystems. These zones are particularly important in the context of adaptation to climate change because even in adverse weather conditions they provide pollution-free, fresh air for polluted settlement areas and can prevent the overheating of urban regions. If water-dependent ecosystems become dryer, then it is to be expected that their potential for climatic balancing will also decline (Wendler et al. 2012, p. 55 et seq.).

\subsection{Recommendations for Integrating Climate Change in RBMP}

In the first river basin management planning documents, climate change was addressed only seldom in most cases mentioned as a potential threat. But within the second planning cycle until 2015 climate change shall be integrated systematically. Therefore, the following recommendations can be given from the perspective of nature conservation (cf. Stratmann et al. 2012a, p. 305 et seq.):

1. Adjusting reference conditions for water bodies and methods for status assessment. Aspects of climate change should be included when assessing the status of water bodies. This should involve the adjustment of climate scenarios for use in the river basin, parameters for monitoring the water-related effects of climate change being incorporated in the monitoring programme, the adjustment-where necessary - of water type specific reference conditions, and the adjustment of status assessment methods. This will create a basis for further planning of objectives and measures that enable climate protection and the effects of climate change to be considered in an integrated manner. This will then allow the formulation of effective measures that are win-win and no regret in terms of climate change.

2. Adjusting risk assessments for groundwater-dependent terrestrial ecosystems. At the moment water extraction that has continued at a constant rate over many years is not further monitored in Germany for instance. Climate change can, 
however, lead to alterations in groundwater levels and runoff from watercourses that over time result in significant damage to groundwater-dependent terrestrial ecosystems. It is thus recommended that the next phase of management planning should include more careful consideration of climate change when carrying out risk assessments for groundwater-dependent terrestrial ecosystems.

3. Adjusting strategies for goal attainment and management objectives. When formulating strategies for goal attainment and aligning management objectives, attention should be paid to further aspects relevant to nature conservation, e.g. climate change and flood protection. These should occur early in the planning process. The timely integration of nature conservation objectives within the frame of coordinated management and measures planning allows to simultaneously achieve these nature protection objectives. If the relevant background documents are clearly named and easily available, then it is probable that the stated objectives will be successfully integrated into further planning stages, particularly the stipulation of measures.

4. Adjusting calculations of the environmental costs of water uses. The effects of climate change on the hydrological regime should be included in the baseline scenario on the basis of up-to-date (regionalised) climate forecasts. As climate change effects can vary in strength according to region, it will probably be necessary to use regionally differentiated adjustments for individual river basins. If regionally significant climate change effects occur, it may be necessary to reassess the environmental costs of water uses, because these may need to be differently measured if water supply changes. In addition, changed climatic conditions may have an influence, e.g. on the setting of environmental objectives, on the prioritisation of measures from a nature conservation perspective and on the planning of measures overall.

5. Conduct a climate check for measures. The process by which measures for the programme of measures are chosen should include a climate check based on upto-date regionalised climate forecasts, to ensure that measures are primarily chosen that for the area in question have positive effects in terms of climate change and protection (win-win) or that will be effective under the influence of different climatic developments (no regret). Such a climate check is recommendable because WFD measures should also be effective over the medium to long-term. Measures should thus be chosen that are also effective under changed climatic conditions. This can indirectly ensure that intended synergies with nature conservation also come into effect under the influence of climate change. The adaptation of aquatic habitats to changed climatic conditions can thus, under the auspices of nature conservation, be particularly encouraged. The German Strategy for Adaptation to Climate Change (Die Bundesregierung 2008), for instance, demands for surface waters that their continuity and diversity of structure be increased and floodplains be regained and reinvigorated. "Appropriate measures (...) should be intensified and implemented in cooperation with the authorities responsible for nature conservation, agriculture and water management and land users" (Die Bundesregierung 2008, p. 27). Furthermore climate protection measures should be preferentially selected (e.g. conservation and 
restoration of wetlands or wet upper soil layers), because current climate protection activities fall far behind the objectives that have been set. In Poland, the Strategic Adaptation Plan is now created on the level of the ministry of environment in order to reveal and mitigate possible negative influences of the climate change to all sectors, including the biodiversity of aquatic ecosystems. However, due to the vast delay of adaptation measures implementation in Poland if compared to the other EU countries, the goals of the programme are only to be achieved before $2020 .^{1}$

\subsection{Conclusion and Outlook on Coordination of Nature Conservation and WFD Implementation}

It can be summarized, that there is great potential for strengthening synergies between water resource management and nature conservation in river basin management planning. This concerns primarily the ecosystem based approach of both WFD and nature conservation and, as regards contents, the ecological development of rivers and streams as well as of banks and meadows, the improvement of habitat networks and the conservation of Natura 2000 sites. In particular, there are many interconnections between Natura 2000 sites and measures of the WFDs programmes of measures. The examination of sensitivities of Appendix II species (Habitats Directive) with respect to the types of measures listed for implementation in accordance with WFD showed that varying sensitivities are to be expected for about half of the protected species concerned.

The potentials for synergies between water resource management and nature conservation are not fully exploited yet. Therefore the degree of substantive detail and the spatial allocation of planning content should be increased. It can be recommended to relate special nature conservation issues, such as Natura 2000 area boundaries including networking elements clearly to the content of water management planning, for example water body boundaries. Furthermore, pragmatic methodological approaches for including costs for species and habitat types covered by the Habitats Directive in the economic analysis should be provided. Last but not least, the participation of the public could be improved, especially as regards nature conservations interests.

But since the measures planned are mostly spatially unspecific so far, potential conflicts and synergies could not yet be discussed in concrete terms. In such cases, determined coordination between nature conservation and water resource management is especially important at subsequent planning levels.

\footnotetext{
1 Further information available at (visited 28th May 2013): http://www.mos.gov.pl/kategoria/ 5145_adaptacja_do_zmian_klimatu.
} 
Climate change causes new framework conditions both for implementing the programmes of measures and for the setting of aims for protected areas, for, e.g., Natura 2000 sites. We have to accept the challenge of climate change, thus climate related objectives should be particularly considered when formulating and implementing environmental strategies and measures. On the one hand, it is necessary to reduce and avoid further climate warming; and, on the other hand, adjustments (according) to climate change must be attempted. Measures should thus be preferred that, in addition to their effectiveness in relation to WFD objectives, also reduce emissions of greenhouse gases (win-win measures) at the same cost. Similarly, preference should be given to measures with a high tolerance to climate change, remaining effective and expedient also under changing climate conditions. In general, due to the ambitious ecological objectives of Art. 4 WFD river basin management planning contributes to increasing the resilience of aquatic and waterdependent ecosystems against climate induced stresses.

The planning instruments are suitable to cope with the requirements named above. The cyclical updating of the plans and programmes and the given flexibility of aims and measures allow for a continuous integration of climate change aspects based on updated data and understanding, and for real changes of circumstances in the river basins.

In conclusion it can be said that nature conservation can benefit from river basin management to great extent. Therefore, the potential synergies should in future be tapped by more concrete planning and presentation, by integrating further aspects of nature conservation in the individual methodological modules of river basin management planning and by good communication and participation.

Open Access This chapter is distributed under the terms of the Creative Commons Attribution Noncommercial License, which permits any noncommercial use, distribution, and reproduction in any medium, provided the original author(s) and source are credited.

\section{References}

Albrecht J, Schmidt C, Stratmann L, Hofmann M, Posselt S, Wendler W, Roßner D, Wachs A (2012) Die Wasserrahmenrichtlinie aus Sicht des Naturschutzes - Analyse der Bewirtschaftungsplanung 2009. In: Naturschutz und Biologische Vielfalt Bonn - Bad Godesberg, vol 120

BMU-Bundesministerium für Umwelt, Naturschutz und Reaktorsicherheit (2007) Conclusion from the international symposium "time to adapt - climate change and the European water dimension". http://www.climate-water-adaptation-berlin2007.org/documents/conclusions.pdf. Accessed 11 June 2013

Carter J, Howe J (2006) The water framework directive and the strategic environmental assessment directive: exploring the linkages. Environ Impact Assess Rev 26(3):287-300

Czychowski M, Reinhardt M (2010) Wasserhaushaltsgesetz, Kommentar, 10th edn, Munich

Die Bundesregierung (2008) Deutsche Anpassungsstrategie an den Klimawandel, vom Bundeskabinett am 17. Dezember 2008 beschlossen. http://www.bmu.de/klimaschutz/downloads/doc/ 42783.php. Accessed 11 June 2013

EC-European Commission (2008) Climate change and water (CIS). Policy paper 
EC-European Commission (2009) River basin management in a changing climate (CIS). Guidance document no. 24

EC-DGEnv (2010) Directorate-General Environment, Directorate B-Nature. Links between the Water Framework Directive (WFD 2000/60/EC) and Nature Directives (Birds Directive 2009/ 147/EC and Habitats Directive 92/43/EEC) - Frequently Asked Question. Draft version 3.4, 1 June 2010. European Commission, Brussels: 16 pp

EEA-European Environment Agency (2007) Technical report no 2/2007. Climate change and water adaptation issues, Copenhagen

Ell M (2003) Wasserrechtliche Planung. Die rechtliche und organisatorische Umsetzung der Wasserrahmenrichtlinie, Baden-Baden

Endlicher W, Gerstengarbe FW (2007) Der Klimawandel - Einblicke, Rückblicke und Ausblicke, Potsdam

Foundation for Water Research (2012) The water framework directive. http://www.euwfd.com/ html/what_is_the_wfd-.html. Accessed 11 June 2013

Fuchs M, Preis S, Wirth V, Binzenhöfer B, Pröbstl U, Pohl G, Muhar S, Jungwirth M (2010) Wasserrahmenrichtlinie und Natura 2000. Gemeinsame Umsetzung in Deutschland und Österreich am Beispiel der Grenzflüsse Salzach und Inn. In: Naturschutz und Biologische Vielfalt, vol 85

Gammeltoft P (2007) Towards an EU policy framework for adaptation. speech 13 february (head of unit water and marine DG environment, European Commission) German presidency conference "climate change and water". Berlin

Hofmann M, Schmidt C (2012) Vertiefende Analyse ausgewählter Schnittstellen, Natura 2000. In: Albrecht J, Schmidt C, Stratmann L, Hofmann M, Posselt S, Wendler W, Roßner D, Wachs A (eds) Die Wasserrahmenrichtlinie aus Sicht des Naturschutzes - Analyse der Bewirtschaftungsplanung 2009. In: Naturschutz und Biologische Vielfalt, vol 120, Bonn - Bad Godesberg: $193-223$

IPCC (2007) 4. Sachstandsbericht des Zwischenstaatlichen Ausschusses für Klimaänderungen

Knopp GM (2005) Bewirtschaftung von Flussgebietseinheiten: Aufgaben, Instrumente und Probleme. In: Bohne E. Ansätze zu einer Kodifikation des Umweltrechts in der Europäischen Union: Die Wasserrahmenrichtlinie und ihre Umsetzung in nationales Recht. Beiträge zum 3. Speyerer UGB-Forum vom 15. bis 16. September 2003 an der Deutschen Hochschule für Verwaltungswissenschaften Speyer. Berlin: 23-33

Korn N, Jessel B, Hasch B, Mühlighaus R (2005) Flussauen und Wasserrahmenrichtlinie, Bedeutung der Flussauen für die Umsetzung der europäischen Wasserrahmenrichtlinie. In: Naturschutz und Biologische Vielfalt, vol 27, Bonn - Bad Godesberg

LAWA - Länderarbeitsgemeinschaft Wasser (2001) Handlungskonzept zur Umsetzung der Wasserrahmenrichtlinie

LAWA — Länderarbeitsgemeinschaft Wasser (2003) Arbeitshilfe zur Umsetzung der EGWasserrahmenrichtlinie. 14 October 2003. http://www.wasserblick.net/servlet/is/195. Accessed 11 June 2013

LAWA —Länderarbeitsgemeinschaft Wasser (2009) Musterkapitel "Klimawandel" für die Bewirtschaftungspläne. Ständiger Ausschuss der LAWA "Hochwasserschutz und Hydrologie (AH)"

LAWA - Länderarbeitsgemeinschaft Wasser (2010) Strategiepapier "Auswirkungen des Klimawandels auf die Wasserwirtschaft". Bestandsaufnahme und Handlungsempfehlungen. beschlossen auf der 139. LAWA-VV am 25/26 März 2010 in Dresden. http://www.lawa.de/ documents/LAWA_Strategiepapier_1006_d07.pdf. Accessed 23 September 2010

Posselt S, Albrecht J, Stratmann L (2012) Die Bewirtschaftungsplanung in den zehn Flussgebietseinheiten Deutschlands. In: Albrecht J, Schmidt C, Stratmann L, Hofmann M, Posselt S, Wendler W, Roßner D, Wachs A, Die Wasserrahmenrichtlinie aus Sicht des Naturschutzes - Analyse der Bewirtschaftungsplanung 2009. In: Naturschutz und Biologische Vielfalt, vol 120, Bonn - Bad Godesberg, pp 75-80

Rechenberg J, Markard C, Irmer U (2000) Die neue Wasserrahmenrichtlinie (II). In: Wasserwirtschaft, Wassertechnik mit Abwasser-technik (wwt awt) 1/2000, pp 41-42 
Reese M (2011) Die Anpassung an den Klimawandel im Bewirtschaftungssystem der Wasserrahmenrichtlinie. Zeitschrift für Was-serrecht (ZfW), pp 61-82

Schuchardt B, Wittig S, Mahrenholz P, Kartschall K, Mäder C, Hasse C, Daschkeit A (2008) Germany in the Midst of climate change: adaptation is necessary. Umweltbundesamt, KomPass (Competence Centre on Climate Impacts and Adaptation), pp 4-13

Seidel W, Rechenberg J (2004) Rechtliche Aspekte des integrativen Gewässermanagements in Deutschland. In: Zeitschrift für Umweltrecht (ZUR), pp 213-221

Spillecke H (2000) Rechtliche Umsetzung der EU-Wasserrahmenrichtlinie. Wasser und Abfall (WuA) 4(2000):30-33

Stratmann L, Hofmann M, Posselt S, Wendler W, Schmidt C, Albrecht J (2012a) Zusammenfassung der Kernempfehlungen. In: Albrecht J, Schmidt C, Stratmann L, Hofmann M, Posselt S, Wendler W, Roßner D, Wachs A (2012) Die Wasserrahmenrichtlinie aus Sicht des Naturschutzes - Analyse der Bewirtschaftungsplanung 2009. In: Naturschutz und Biologische Vielfalt, vol 120, Bonn - Bad Godesberg, pp 305-318

Stratmann L, Wendler W, Posselt S, Albrecht J (2012b) Vergleichende Auswertung der Bewirtschaftungspläne. In: Albrecht J, Schmidt C, Stratmann L, Hofmann M, Posselt S, Wendler W, Roßner D, Wachs A, Die Wasserrahmenrichtlinie aus Sicht des Naturschutzes Analyse der Bewirtschaftungsplanung 2009. In: Naturschutz und Biologische Vielfalt, vol 120, Bonn - Bad Godesberg, pp 86-119

Stratmann L, Wendler W, Posselt S, Albrecht J (2012c) Vergleichende Auswertung der Umweltberichte. In: Albrecht J, Schmidt C, Stratmann L, Hofmann M, Posselt S, Wendler W, Roßner D, Wachs A, Die Wasserrahmenrichtlinie aus Sicht des Naturschutzes - Analyse der Bewirtschaftungsplanung 2009. In: Naturschutz und Biologische Vielfalt, vol 120, Bonn - Bad Godesberg, pp 141-160

Wendler W, Albrecht J (2012) Ziele von Wasserrahmenrichtlinie und Naturschutz. In: Albrecht J, Schmidt C, Stratmann L, Hofmann M, Posselt S, Wendler W, Roßner D, Wachs A, Die Wasserrahmenrichtlinie aus Sicht des Naturschutzes - Analyse der Bewirtschaftungsplanung 2009. In: Naturschutz und Biologische Vielfalt, vol 120, Bonn - Bad Godesberg, pp 23-44

Wendler W, Albrecht J, Stratmann L (2012) Naturschutzrelevante Inhalte der Bewirtschaftungsplanung. In: Albrecht J, Schmidt C, Stratmann L, Hofmann M, Posselt S, Wendler W, Roßner D, Wachs A (2012) Die Wasserrahmenrichtlinie aus Sicht des Naturschutzes - Analyse der Bewirtschaftungsplanung 2009. In: Naturschutz und Biologische Vielfalt, vol 120, Bonn - Bad Godesberg, pp 45-64

Wulfhorst J (2010) Klimawandel, Hochwasser und Trockenfallen von Fließgewässern: Einfluss eines Abfluss-Regimes mit geringer Vorhersagbarkeit und sehr hoher Unregelmäßigkeit auf die Lebensgemeinschaften von zwei Waldbächen im Westharz. Treffpunkt Biologische Vielfalt IX. In: BfN-Skripten, vol 265, Bonn - Bad Godesberg, pp 89-96 